\title{
Insights into the European rabbit (Oryctolagus cuniculus) innate immune system: genetic diversity of the toll-like receptor 3 (TLR3) in wild populations and domestic breeds
}

\author{
Joana Abrantes ${ }^{1,3}$, Helena Areal ${ }^{1,2}$ and Pedro J Esteves ${ }^{1,4^{*}}$
}

\begin{abstract}
Background: Toll-like receptors (TLRs) belong to the innate immune system and are a major class of pattern recognition receptors representing the first line of the innate immune response. The TLR molecule is structurally composed by an ectodomain that contains leucine rich repeats (LRRs) that interact with pathogen associated molecular patterns (PAMPs), a transmembrane domain and a conserved cytoplasmic domain designated TIR (Toll-IL1 receptor) that is responsible for the intracellular signaling. TLR3 has been associated with the direct recognition of double-stranded viral RNA resulting from viral replication, while TLR7 and TLR8 target single-stranded viral RNA. In the European rabbit (Oryctolagus cuniculus), TLR7 and TLR8 were reported to be absent and pseudogenised, respectively, making TLR3 the only available TLR for the recognition of viral RNA. Thus, the levels of diversity of TLR3 were evaluated in the European rabbit by analysing different genetic backgrounds and exposure to pathogen pressures.
\end{abstract}

Results: We detected 41 single nucleotide polymorphisms (SNPS) in the coding sequence of TLR3. The highest diversity was observed in the wild populations of Iberian Peninsula, between 22-33 polymorphic positions. In the French population, 18 SNPs were observed and only 4 polymorphic positions were detected in the domestic breeds. 14 non-synonymous substitutions were observed, most of them in the LRR molecules. The remaining were scattered across the transmembrane and TIR domains.

Conclusion: The study of TLR3 in European rabbit populations might be relevant to understand the interplay between RNA viruses and innate immunity. Wild rabbit populations presented more diversity than domestic breeds and other mammals previously studied. This might be linked to the absence of population bottlenecks during their evolution and to the almost inexistence of man-mediated selection. The observed variability might have also been potentiated by the contact of the wild populations with various pathogens. The study of these patterns of variability might reveal scenarios of host-pathogen interaction and identify TLR3 polymorphisms' that arose due to viral pathogens affecting wild populations.

Keywords: Toll-like receptor 3 (TLR3), European rabbit (Oryctolagus cuniculus), RNA virus, Genetic diversity

\footnotetext{
* Correspondence: pjesteves@cibio.up.pt

${ }^{1} \mathrm{CIBIO} / \mathrm{UP}$, Centro de Investigacao em Biodiversidade e Recursos Geneticos/

Universidade do Porto, InBio, Laboratorio Associado, Campus Agrario de

Vairao, Rua Padre Armando Quintas, number. 7, Vairao 4485-661, Portugal

${ }^{4}$ CESPU, Instituto de Investigação e Formação Avançada em Ciências e

Tecnologias da Saúde, Gandra, Portugal

Full list of author information is available at the end of the article
} 


\section{Background}

The Toll like receptor (TLR) molecules are pattern recognition receptors (PRR) that mediate the recognition of pathogens by the innate immune system and can also lead to the activation of the adaptive immune response. To date, thirteen mammalian TLRs have been described that recognise pathogen associated molecular patterns (PAMPs), including bacterial lipoproteins, lipopolysaccharide (LPS) and viral nucleic acids [1]. TLR3 is triggered directly by double-stranded RNA (dsRNA) viruses or dsRNA resulting from their replication process [2]. The human TLR3 molecule is structurally characterised by the presence of an ectodomain that encompasses 23 leucine-rich repeats (LRRs) capped at each end by a LRR-NT and a LRR-CT molecule $[3,4]$. The LRRs main function is the interaction with PAMPs which in TLR3 occurs in the concave face of the TLR3-TLR3 homodimer [5]. In addition, human TLR3 has a transmembrane domain and a conserved cytoplasmic domain homologous to interleukin-1 receptor (IL1R) and IL-18 receptor (IL18R) designated TIR domain that is responsible for the intracellular signalling [5-7].

The lack of this receptor has been associated with higher susceptibility and mortality in infections by cytomegalovirus (CMV) and herpes simplex virus (HSV) in mice and humans $[8,9]$. On the other hand, some viruses, like West Nile Virus (WNV), benefit from the interaction with TLR3 that facilitates infection and dissemination in the organism [10]. In line with this disease association, several studies have pointed out a link between polymorphisms in TLR3 and resistance/susceptibility to diseases $[11,12]$. For instance, in humans, the TLR3 single nucleotide polymorphism (SNPs) involved in the amino acid replacement N284I is responsible for the partial or total loss of activity of the receptor possibly by destabilising LRR architecture and the P554S SNP is associated with encephalitis caused by HSV [3]

In the present study a general approach was made to assess TLR3 diversity in wild and domestic European rabbits (Oryctolagus cuniculus) that have different genetic backgrounds and are exposed differently to pathogens. Viral TLRs (TLR3, 7, 8 and 9) act as the first line of defence against viral pathogens. However, in rabbit, TLR7 and TLR8 which are responsible for the recognition of ssRNA viruses are absent or pseudogenised, respectively [13], making TLR3 the only available TLR for the recognition of viral RNA.

The European rabbit originated in the Iberian Peninsula (IP) where two subspecies that diverged about 2 million years ago co-exist: Oryctolagus cuniculus algirus (OCA) in the Southwest part and Oryctolagus cuniculus cuniculus (OCC) in the Northeast part of IP [14] (Figure 1). More recently, the Northeast populations expanded to France and from these the species has been domesticated in the last 1,500 years with more than 200 breeds currently being recognised [15]. Thus, rabbit populations found outside the IP represent a subset of the original gene pool. Here, we have characterised genetically the TLR3 coding sequence in wild rabbits from the Iberian Peninsula and from France, and from domestic animals from 4 different breeds (Table 1) that represent different genetic backgrounds and which are exposed to different pathogen pressures aiming at finding polymorphisms that might interfere with the TLR3 function.

\section{Results and discussion}

According to Ensembl (www.ensembl.org; ENSOCUG000 00017763), TLR3 is assigned to chromosome 2 of the European rabbit genome, with a total length of $11762 \mathrm{bp}$. The gene is organised into 4 or 5 exons with the coding sequence (CDS) comprising $2718 \mathrm{bp}$ and $2655 \mathrm{bp}$, respectively. These transcripts translate into 905 and 884 amino acids, respectively, with the shorter transcript having a 21 amino acid deletion at exon 3 corresponding to amino acids 783-803. The analysis of the TLR3 structure revealed the presence of an ectodomain with a LRR-NT, twenty four LRRs and a LRR-CT, a transmembrane and TIR domains (Figure 2). This structure is in agreement to that of other TLRs.

Several studies addressing the TLR3 genetic variation showed low levels of diversity in many mammals. Indeed, in nine breeds of bovines, seven SNPs were found of which three were non-synonymous [11]. In addition, in 84 male pigs from eleven breeds nine synonymous SNPs and six non-synonymous were detected [22] while in five horse breeds four SNPs were described of which two are non-synonymous [13]. Here we detected 41 SNPs in the coding sequence of TLR3 of which 14 are non-synonymous (Additional file 1: Table S1). This discrepancy in values could be due to the inclusion of wild animals in the present study which were not considered in the species previously described, and which in turn might have contributed for the higher levels of diversity found here. In particular, the results showed higher diversity in the OCA populations where 33 polymorphic positions were observed, whereas only 22 were observed in OCC from IP, 18 in OCC from France and only 4 in the domestic breeds (Table 2). These results are further confirmed by the population genetic parameters summarised in Table 2. Even though no diagnostic positions were observed, some were exclusive to each population (Table 2). In addition, a gradient of genetic diversity loss in the same direction as the domestication process (from the Iberian populations to the French populations; Table 2) seems to occur as expected due to the bottleneck effect associated with this process [16]. However, the Tajima D's test did not reject the null hypothesis that the populations evolve under neutrality (Table 2). 


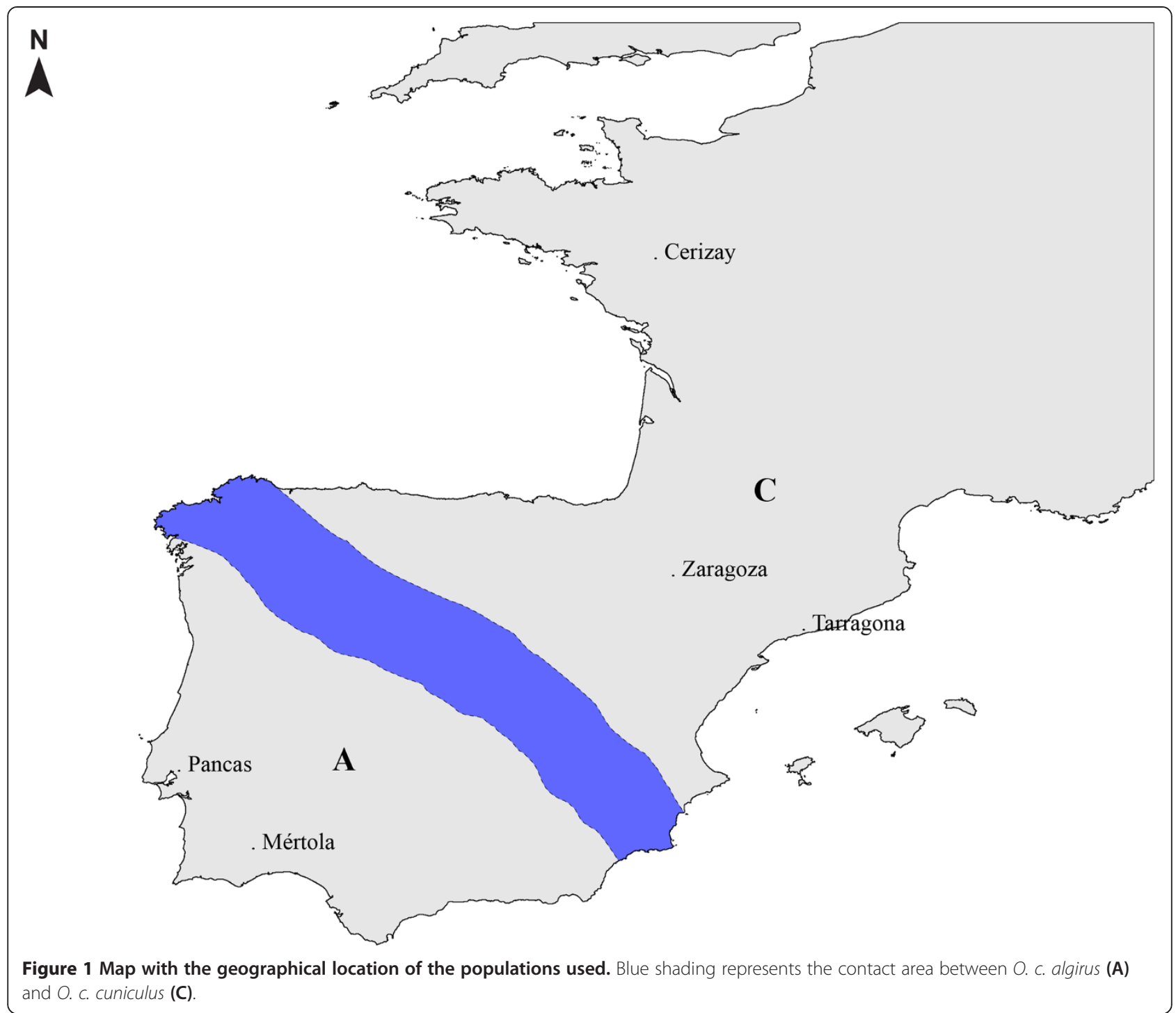

Table 1 List of the samples used including information regarding their subspecies/breed, country, sampling locality, number of individuals and reference to previous studies

\begin{tabular}{ccccc}
\hline $\begin{array}{c}\text { Subspecies } \\
\text { (breed) }\end{array}$ & Country & Locality & $\begin{array}{c}\text { Number of } \\
\text { individuals }\end{array}$ & References \\
\hline O. c. algirus & Portugal & Pancas & 10 & {$[14,16,17]$} \\
& & Mértola & 10 & {$[14]$} \\
O. c. cuniculus & Spain & Zaragoza & 10 & {$[14,16,17]$} \\
& & Tarragona & 10 & {$[14,16,17]$} \\
& France & Cerisay & 20 & {$[18,19]$} \\
French Lop & n.a. & n.a. & 5 & {$[20]$} \\
English Spot & n.a. & n.a. & 5 & {$[20]$} \\
Argent & n.a. & n.a. & 5 & {$[20]$} \\
Champagne & & & 5 & {$[20]$} \\
New Zealand & n.a. & n.a. & & \\
\hline
\end{tabular}

n.a. not applicable.
Seventy-five haplotypes were recovered of which the majority $(64 / 75 \approx 85 \%)$ are rare occurring only once in heterozigoty and only two (haplotypes 39 and 40) are shared between different populations (see Additional file 2: Table S2). Indeed, haplotype 39 is common in OCC from IP and France and all domestic breeds, which is expected as these are the closest populations. Haplotype 40 is more restricted and shared only by Iberian OCC from Tarragona and France and the English Spot breed. It is also interesting to note that OCA populations do not share haplotypes with the other subspecies neither among the two populations which reveal a high degree of genetic variability across individuals. With respect to the domestic individuals, all specimen from French Lop, Argent Champagne and New Zealand are characterised by presenting a single haplotype while in the English Spot breed 3 different haplotypes are present. The estimation of haplotype diversity showed a pattern of loss of genetic diversity from 


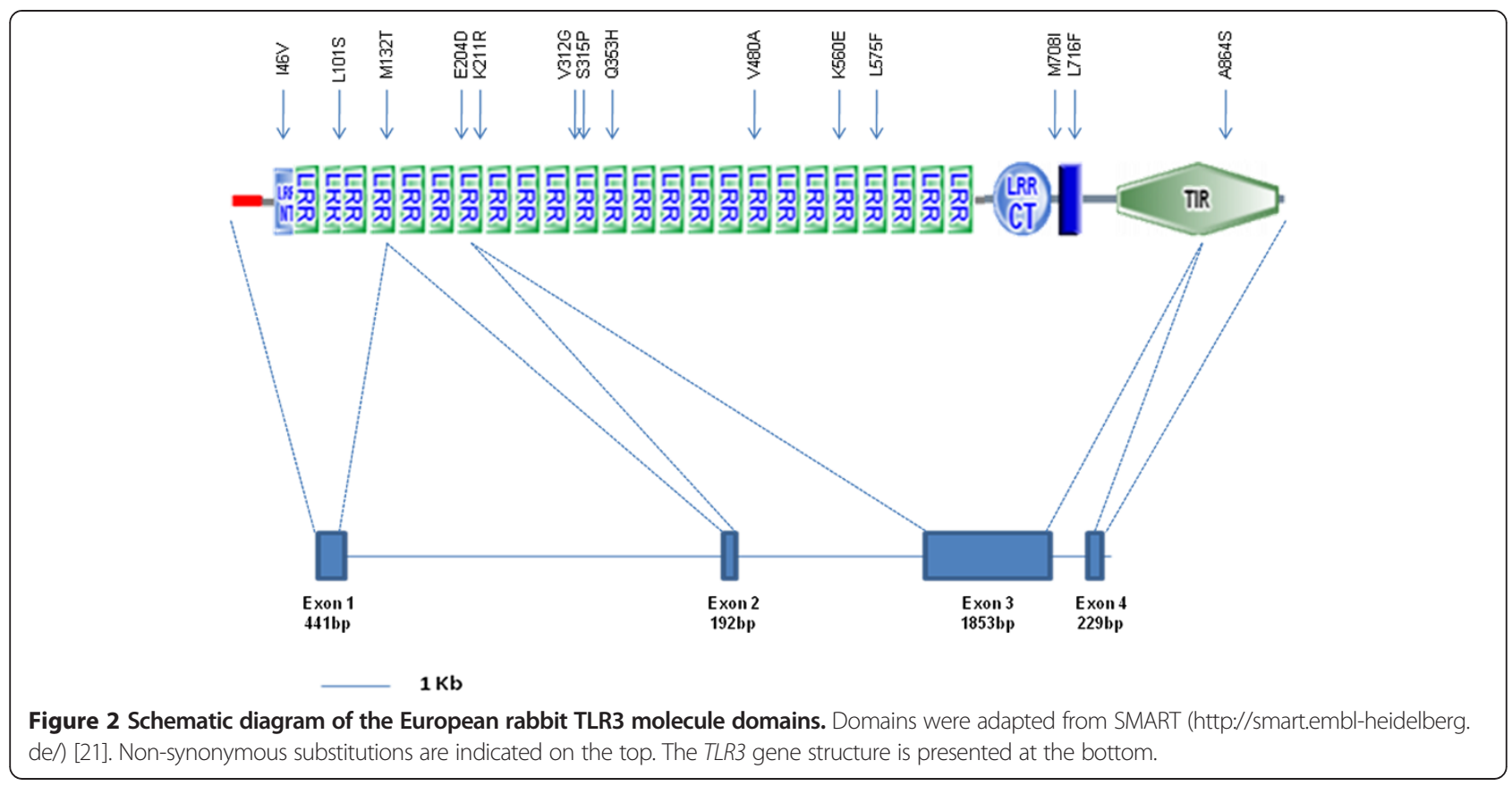

the Iberian to the French populations (Table 3). As expected, the lowest values were observed for the domestic breeds. The higher variability in the wild populations may be due to the absence of man-mediated selection and a greater exposure to pathogens. Additionally, the low genetic diversity observed for the French populations when comparing with the IP populations might be explained because they are a subsample of the Iberian OCC which has recently colonised France $[20,25,26]$.

Of the total number of polymorphisms, $\approx 34 \%(14 / 41)$ are non-synonymous substitutions that could be a source of protein variability that might interfere in the ability of TLR3 to recognise ligands and lead to

Table 2 Levels of nucleotide sequence polymorphism in the populations/domestic studied for TLR3

\begin{tabular}{lcccc}
\hline All & $\mathbf{N}$ & $\mathbf{S}$ & $\boldsymbol{\pi}$ & $\mathbf{D}$ \\
\hline O. c. algirus & $\mathbf{1 6 0}$ & $\mathbf{4 1}$ & $\mathbf{0 . 0 0 2 7}$ & $\mathbf{- 0 . 0 0 1 5}$ \\
Portugal & 40 & 33 & 0.0031 & 0.3310 \\
$\quad$ Pancas & 20 & 23 & 0.0023 & -0.1429 \\
$\quad$ Mértola & 20 & 30 & 0.0035 & 0.4839 \\
O. c. cuniculus & & & & \\
Spain & 40 & 22 & 0.0024 & 0.8565 \\
$\quad$ Zaragoza & 20 & 18 & 0.0022 & 0.7376 \\
$\quad$ Tarragona & 20 & 19 & 0.0023 & 0.6632 \\
France & 40 & 18 & 0.0025 & 1.9930 \\
Domestic & 40 & 4 & 0.0004 & 0.2620 \\
\hline
\end{tabular}

$\mathrm{N}$, number of sequences; $\mathrm{S}$, number of segregating sites; $\pi$, nucleotide diversity [23]; D, Tajima's D statistic test [24]. resistance/susceptibility to viral diseases (Table 4). In particular, the variation observed at residues 480, 560 and 864 is unique to the European rabbit as these amino acids are generally conserved among mammals (data not shown). Although no data associate the observed substitutions with disease, it is likely that populations that are in contact with different pathogenic agents co-evolve with them and display more genetic diversity in order to confer resistance. Examples of two viral diseases responsible for high mortalities in domestic and wild European rabbits are RHDV and myxomatosis $[27,28]$. This variation could however be just the result of stochastic events that occurred during evolution of the protein.

Table 3 Estimates of haplotype diversity, haplotype diversity variance and haplotype standard deviation in the populations/domestic studied for TLR3

\begin{tabular}{lcccc}
\hline All & $\mathbf{H}$ & $\mathbf{H d}$ & Hd variance & Hd std deviation \\
\hline O. c. algirus & $\mathbf{7 5}$ & $\mathbf{0 . 8 8 3}$ & $\mathbf{0 . 0 0 0 5 1}$ & $\mathbf{0 . 0 2 3}$ \\
Portugal & 38 & 0.997 & 0.00004 & 0.006 \\
$\quad$ Pancas & 18 & 0.989 & 0.00037 & 0.019 \\
$\quad$ Mértola & 20 & 1.000 & 0.00025 & 0.016 \\
O. c. cuniculus & & & & \\
Spain & 28 & 0.969 & 0.00025 & 0.016 \\
$\quad$ Zaragoza & 16 & 0.974 & 0.00063 & 0.025 \\
$\quad$ Tarragona & 13 & 0.911 & 0.00289 & 0.054 \\
France & 9 & 0.763 & 0.00227 & 0.048 \\
Domestic & 4 & 0.310 & 0.0077 & 0.088 \\
\hline
\end{tabular}

$\mathrm{H}$, number of haplotypes; $\mathrm{Hd}$, haplotype diversity; $\mathrm{Hd}$ variance, variance of haplotype diversity; Hd std deviation, standard deviation of haplotype diversity. 
Regarding the location of the amino acid changes, most (11) are in the LRR molecules and the remaining (3) are distributed across the transmembrane and TIR domains (Figure 2). The higher variation in the LRRs is expected as these molecules are responsible for the direct interaction with PAMPs and should evolve to maintain recognition and trigger the innate immune response. The interaction between TLR3 and dsRNA occurs in two binding sites localised in the region comprising LRR-NT and LRR3 and LRR19-20 [3]. Of the non-synonymous substitutions observed in the LRRs, three are located within these interaction points. Nevertheless, none of these alterations (p. I46V in the LRR-NT, p.L101S in LRR2 and p.K560E in LRR20; Table 4) is conserved among vertebrates (data not shown) or essential for recognition [29,30]. LRR20, along with LRR21 and LRR22, are known for their importance in binding and signalling [31], but the p.L575F alteration observed in the LRR20 is conservative.

Other regions in the ectodomain have also been described as being important for ligand binding such as those between R65 to K163 and K330 to K493 that were described by Choe, Kelker et al. (2005) as a patch of positively charged residues [31]. In this region, of the four amino acid changes observed in this study, only one (p. Q353H; Figure 2 and Table 4) results in changes in the polarity. The importance of the ectodomain in the PAMPs recognition as well as the role of the possible coevolution with the pathogens they recognise in the evolution of this domain has been a recurrent matter particularly shown in the high level of positive selection in this domain across mammal TLRs [32]. This supports that the changes observed in the ectodomain of TLR3 might be the result of adaptation of TLR3 to maintain recognition of the evolving viral PAMPs. Nonetheless, none of the nonsynonymous substitutions here detected is located within the sites detected previously as being under positive selection in mammals [32].

In the transmembrane domain, two amino acid changes were found, but both are conservative in terms of polarity and charge. In contrast, the alteration in the TIR domain, A864S (Figure 2 and Table 4), results in change of a hydrophobic residue for one hydrophilic corresponding to a possible site of $\mathrm{N}$-glycosylation that may have consequences in the functionality of this domain. The TLR3 molecule is highly glycosylated in its ectodomain where there are 15 predicted N-glycosylation sites that affect ligand binding or control the access to the interaction surfaces [3]. Ligand binding in TLR3 only occurs at the glycan-free surface [31]. Despite this, the functional consequences of a possible N-glycosylation site in the TIR domain are unknown.

The biological consequences of each of the described alterations in the TLR3 molecule of the European rabbit also remains unknown, but further studies should be conducted to assess their impact since in this species only this TLR is available for detection of RNA viruses.

\section{Conclusions}

The differences in the TLR3 genetic variability detected between the wild rabbit populations and the domestic breeds reflects the domestication process of this species but might also result from the different exposure to pathogens. Indeed, while wild populations are usually in contact with a higher number of pathogens, domestic breeds are usually bred in highly controlled facilities. The higher number of non-synonymous substitutions found in the ectodomain, which corresponds to the binding surface to the PAMPs, further suggests a role of the host-pathogen interaction in promoting variability. In addition, the limited degree of variability found in the domestic breeds might compromise survival in face of a viral infection putting at risk the studied breeds.

\section{Methods}

The program LRRfinder was used to determine the European rabbit TLR3 domain structure [33] (http:// www.lrrfinder.com/).

In this study we analysed 20 individuals of the subspecies Oryctolagus cuniculus cuniculus from Spain (Tarragona (OCCIP_T) and Zaragoza (OCCIP_Z)) and 20 of the subspecies Oryctolagus cuniculus algirus from Portugal (Pancas (OCA_P) and Mertola (OCA_M)). These natural

Table 4 Amino acid variation found at TLR3 in each population/domestic

\begin{tabular}{|c|c|c|c|c|c|c|c|c|c|c|c|c|c|c|c|}
\hline \multirow[b]{2}{*}{ Subspecies } & \multirow[b]{2}{*}{ Population } & \multicolumn{14}{|c|}{ Position } \\
\hline & & \multirow{2}{*}{$\begin{array}{c}46 \\
\text { I }\end{array}$} & \multirow{2}{*}{$\begin{array}{c}101 \\
\mathbf{L}\end{array}$} & \multirow{2}{*}{$\begin{array}{c}132 \\
\mathbf{M}\end{array}$} & \multirow{2}{*}{$\begin{array}{c}204 \\
\text { E }\end{array}$} & \multirow{2}{*}{$\begin{array}{c}211 \\
\mathbf{K}\end{array}$} & \multirow{2}{*}{$\begin{array}{c}312 \\
\mathbf{v}\end{array}$} & \multirow{2}{*}{$\begin{array}{c}315 \\
\mathbf{S}\end{array}$} & \multirow{2}{*}{$\begin{array}{c}353 \\
\mathbf{Q}\end{array}$} & \multirow{2}{*}{$\begin{array}{c}408 \\
\text { S }\end{array}$} & \multirow{2}{*}{$\begin{array}{c}560 \\
\text { K }\end{array}$} & \multirow{2}{*}{$\begin{array}{c}575 \\
\mathbf{L}\end{array}$} & \multirow{2}{*}{$\begin{array}{c}708 \\
\text { M }\end{array}$} & \multirow{2}{*}{$\begin{array}{c}716 \\
\mathbf{L}\end{array}$} & \multirow{2}{*}{$\begin{array}{c}864 \\
\text { S }\end{array}$} \\
\hline ENSOCUTOC & 00017763 & & & & & & & & & & & & & & \\
\hline \multirow[t]{2}{*}{ O. c. algirus } & Pancas & I & $\mathrm{L} / \mathrm{S}$ & M & $E$ & $\mathrm{~K} / \mathrm{R}$ & V & $\mathrm{S}$ & Q & $\mathrm{V} / \mathrm{A}$ & K & $\mathrm{F}$ & M & $L / F$ & $\mathrm{~A} / \mathrm{S}$ \\
\hline & Mertola & । & $\mathrm{L} / \mathrm{S}$ & M & $\mathrm{E} / \mathrm{D}$ & $\mathrm{K} / \mathrm{R}$ & V & S & $\mathrm{Q} / \mathrm{H}$ & V & K & $\mathrm{F}$ & $M / I$ & $L / F$ & $\mathrm{~A} / \mathrm{S}$ \\
\hline \multirow[t]{4}{*}{ O. c. cuniculus } & Tarragona & IN & $\mathrm{L} / \mathrm{S}$ & $M / T$ & $\mathrm{E}$ & K & v & $S / P$ & Q & V & K & $\mathrm{F} / \mathrm{L}$ & M & $\mathrm{L} / \mathrm{F}$ & $\mathrm{A} / \mathrm{S}$ \\
\hline & Zaragoza & I & $\mathrm{L} / \mathrm{S}$ & $M / T$ & $E / D$ & K & V & S & Q & V & K/E & $\mathrm{F} / \mathrm{L}$ & M & $\mathrm{L} / \mathrm{F}$ & A \\
\hline & Cerisay & । & $\mathrm{L} / \mathrm{S}$ & M & $E$ & K & V/G & S & Q & V & K & $\mathrm{F} / \mathrm{L}$ & M & $\mathrm{L} / \mathrm{F}$ & A \\
\hline & Domestic & I & $L$ & M & $E$ & K & V & S & Q & V & K & $F^{*}$ & M & L & A \\
\hline
\end{tabular}

*only in the English Spot breed: F/L. 
populations are located within the species' original range. Twenty individuals from a French population (Cerisay (OCCF)) and 20 domestic animals (5 individuals per breed (DOM)) belonging to the French Lop, English Spot, Argent Champagne and New Zealand breeds were also studied (Table 1). DNA was extracted with the phenol-chloroform method [34]. Amplification was carried out with Taq DNA Polymerase (Taq PCR Master Mix Kit, Qiagen) with several sets of primers (see Additional file 3: Table S3). The thermal profile consisted of a denaturation of $95^{\circ} \mathrm{C}$ for $15 \mathrm{~min}$ and then, 30 cycles of $95^{\circ} \mathrm{C}$ for 30s; optimal annealing temperature for $30 \mathrm{~s} ; 72^{\circ} \mathrm{C}$ for $45 \mathrm{~s}$ and a final amplification at $60^{\circ} \mathrm{C}$ for $20 \mathrm{~min}$. PCR amplicons of the expected size were sequenced with BigDye ${ }^{\circ}$ Terminator v3.1 Cycle Sequencing Kit (Applied Biosystems, Foster City) in the following temperatures: $94^{\circ} \mathrm{C}$ for $3 \mathrm{~min}, 23$ cycles at $96^{\circ} \mathrm{C}$ for $10 \mathrm{~s}, 55^{\circ} \mathrm{C}$ for $5 \mathrm{~s}$ and $60^{\circ} \mathrm{C}$ for $4 \mathrm{~min}$. The electropherogram analysis was performed in 3130xl Genetic Analyzer (Applied Biosystems, Foster City).

Sequences were edited, aligned and analysed with CLUSTAL W [35] as implemented in the BioEdit software [36]. Haplotype reconstruction was obtained for each individual using PHASE (Version 2.1) [37] as implemented in DnaSP (Version 5.10.01) [38]. Only haplotypes with $\mathrm{P}>0.90$ were considered as inferred reliably. Population genetic parameters $(S, \pi)$, Tajima's $D$, number of haplotypes, haplotype diversity, variance of haplotype diversity and standard deviation of haplotype diversity were estimated with DnaSP. The sequences obtained were also aligned and compared to the reference sequence available in Ensembl (ENSOCUT00000017763).

\section{Availability of supporting data}

Data obtained in this study was submitted to GenBank under the following accession numbers: KC963181 to KC963340.

\section{Ethics for field studies}

All sampling collection was conducted in accordance with local legislation and with the permissions and licences of the National institutions that supervise the hunting activities. The Convention on Biological Diversity and the Convention on the Trade in Endangered Species of Wild Fauna were respected.

\section{Additional files}

Additional file 1: Table S1. List of the SNPs found for each population/ breed and their location in the TLR3 gene (positions are according to the CDS of ENSOCUTO0000017763 from Ensembl).

Additional file 2: Table S2. List of the TLR3 haplotypes found with indication of their frequency and occurrence in the populations/breeds analysed.
Additional file 3: Table S3. Amplification conditions of $T L R 3$.

Characterisation of the conditions used for TLR3 amplification. Positions are according to the rabbit TLR3 sequence (ENSOCUG00000017763).

\section{Abbreviations}

TLR: Toll-like receptor; LRR: Leucine-rich repeats; PAMP: Pathogen associated molecular pattern; TIR: Toll-IL1 receptor; SNP: Single nucleotide polymorphism; PRR: Pattern recognition receptor; LPS: Lipopolysaccharide; dsRNA: Double-stranded RNA; IL1R: Interleukin 1-receptor; IL18R: Interleukin 18-receptor; CMV: Cytomegalovirus; HSV: Herpes simplex virus; WNV: West Nile virus; IP: Iberian Peninsula; OCA: Oryctolagus cuniculus algirus; OCA: Oryctolagus cuniculus cuniculus; CDS: Coding sequence.

\section{Competing interests}

The authors declare that they have no competing interests.

\section{Authors' contributions}

JA and PJE conceived of the study, participated in its design and coordination and helped to interpret data and draft the manuscript. HA carried out the experimental work and analysed the data. All authors read and approved the final manuscript.

\section{Acknowledgements}

The Portuguese Foundation for Science and Technology supported the doctoral fellowship of Helena Areal (SFRH/BD/74948/2010) and the postdoctoral fellowship of Joana Abrantes (SFRH/BPD/73512/2010) as well as the project PTDC/CVT/108490/2008. We are grateful to the Fédération Française de Cuniculture, Union des Sélectionneurs Avicoles du Sud Ouest, Société central d'Aviculture de France, Union des Aviculteurs du Haut-Rhin, Groupement Avicole Pyrénées Atlantiques et Landes, Lapin Club du Sud-Ouest, J. Ruesche, D. Allain, and G. Saleil for providing the domestic rabbit samples.

\section{Author details}

${ }^{1} \mathrm{CIBIO} / \mathrm{UP}$, Centro de Investigacao em Biodiversidade e Recursos Geneticos/ Universidade do Porto, InBio, Laboratorio Associado, Campus Agrario de Vairao, Rua Padre Armando Quintas, number. 7, Vairao 4485-661, Portugal. ${ }^{2}$ Departamento de Zoologia e Antropologia da Faculdade de Ciencias da Universidade do Porto, Porto, Portugal. ${ }^{3}$ INSERM, U892, Universite de Nantes, Nantes 44007, France. ${ }^{4}$ CESPU, Instituto de Investigação e Formação Avançada em Ciências e Tecnologias da Saúde, Gandra, Portugal.

Received: 29 January 2013 Accepted: 12 August 2013

Published: 21 August 2013

\section{References}

1. Takeuchi O, Akira S: Pattern recognition receptors and inflammation. Cell 2010, 140(6):805-820

2. Alexopoulou L, Holt AC, Medzhitov R, Flavell RA: Recognition of double-stranded RNA and activation of NF-kappaB by toll-like receptor 3. Nature 2001, 413(6857):732-738.

3. Botos I, Liu L, Wang Y, Segal DM, Davies DR: The toll-like receptor 3:dsRNA signaling complex. Biochim Biophys Acta 2009, 1789(9-10):667-674.

4. Bell JK, Botos I, Hall PR, Askins J, Shiloach J, Segal DM, Davies DR: The molecular structure of the toll-like receptor 3 ligand-binding domain. Proc Natl Acad Sci USA 2005, 102(31):10976-10980.

5. Bell JK, Mullen GE, Leifer CA, Mazzoni A, Davies DR, Segal DM: Leucine-rich repeats and pathogen recognition in toll-like receptors. Trends Immunol 2003, 24(10):528-533.

6. Beutler B, Jiang Z, Georgel P, Crozat K, Croker B, Rutschmann S, Du X, Hoebe $K$ : Genetic analysis of host resistance: toll-like receptor signaling and immunity at large. Annu Rev Immunol 2006, 24:353-389.

7. Medzhitov R, Janeway CA Jr: Innate immunity: the virtues of a nonclonal system of recognition. Cell 1997, 91(3):295-298.

8. Tabeta K, Georgel P, Janssen E, Du X, Hoebe K, Crozat K, Mudd S, Shamel L, Sovath S, Goode J, et al: Toll-like receptors 9 and 3 as essential components of innate immune defense against mouse cytomegalovirus infection. Proc Natl Acad Sci USA 2004, 101(10):3516-3521.

9. Zhang J, Ugolini S, Smahi A, Elain G, Romero P, Segal D, Sancho-Shimizu V Lorenzo L, Puel A, et al: TLR3 Deficiency in patients with herpes simplex encephalitis. Science 2007, 317(5844):1522-1527. 
10. Wang T, Town T, Alexopoulou L, Anderson JF, Fikrig E, Flavell RA: Toll-like receptor 3 mediates West Nile virus entry into the brain causing lethal encephalitis. Nat Med 2004, 10(12):1366-1373.

11. Cargill EJ, Womack JE: Detection of polymorphisms in bovine toll-like receptors 3, 7, 8, and 9. Genomics 2007, 89(6):745-755.

12. Uenishi $H$, Shinkai $H$ : Porcine toll-like receptors: the front line of pathogen monitoring and possible implications for disease resistance. Dev Comp Immunol 2009, 33(3):353-361.

13. Astakhova NM, Perelygin AA, Zharkikh AA, Lear TL, Coleman SJ, MacLeod JN, Brinton MA: Characterization of equine and other vertebrate TLR3, TLR7, and TLR8 genes. Immunogenetics 2009, 61(7):529-539.

14. Carneiro M, Ferrand N, Nachman MW: Recombination and speciation: loci near centromeres are more differentiated than loci near telomeres between subspecies of the European rabbit (Oryctolagus cuniculus). Genetics 2009, 181(2):593-606.

15. Whitman B: Domestic rabbits and their histories. Leawodd (Kansas): Leathers Publishing; 2004.

16. Carmo CR, Esteves PJ, Ferrand N, van der Loo W: Genetic variation at chemokine receptor CCR5 in leporids: alteration at the 2 nd extracellular domain by gene conversion with CCR2 in Oryctolagus, but not in Sylvilagus and Lepus species. Immunogenetics 2006, 58(5-6):494-501.

17. Carneiro M, Blanco-Aguiar JA, Villafuerte R, Ferrand N, Nachman MW: Speciation in the European rabbit (Oryctolagus cuniculus): islands of differentiation on the X chromosome and autosomes. Evolution 2010, 64(12):3443-3460.

18. Guillon P, Ruvoen-Clouet N, Le Moullac-Vaidye B, Marchandeau S, Le Pendu $\mathrm{J}$ : Association between expression of the $\mathrm{H}$ histo-blood group antigen, alpha1,2fucosyltransferases polymorphism of wild rabbits, and sensitivity to rabbit hemorrhagic disease virus. Glycobiology 2009, 19(1):21-28.

19. Marchandeau S, Le Gall-Recule G, Bertagnoli S, Aubineau J, Botti G, Lavazza A: Serological evidence for a non-protective RHDV-like virus. Vet Res 2005, 36(1):53-62

20. Carneiro M, Afonso S, Geraldes A, Garreau H, Bolet G, Boucher S, Tircazes A, Queney G, Nachman MW, Ferrand N: The genetic structure of domestic rabbits. Mol Biol Evol 2011, 28(6):1801-1816.

21. Letunic I, Doerks T, Bork P: SMART 6: recent updates and new developments. Nucleic acids research 2009, 37(Database issue):D229-232.

22. Morozumi T, Uenishi H: Polymorphism distribution and structural conservation in RNA-sensing toll-like receptors 3, 7, and 8 in pigs. Biochim Biophys Acta 2009, 4:267-274.

23. Nei M: Molecular evolutionary genetics. COLUMBIA: University Press; 1987.

24. Tajima F: Statistical method for testing the neutral mutation hypothesis by DNA polymorphism. Genetics 1989, 123(3):585-595.

25. Esteves Lanning D, Ferrand N, Knight KL, Zhai SK, Van der Loo W: Allelic variation at the $\mathrm{VHa}$ locus in natural populations of rabbit (Oryctolagus cuniculus, L.). J Immunol 2004, 172(2):1044-1053.

26. Surridge AK, van der Loo W, Abrantes J, Carneiro M, Hewitt GM, Esteves PJ: Diversity and evolutionary history of the MHC DQA gene in leporids. Immunogenetics 2008, 60(9):515-525.

27. Kerr PJ: Myxomatosis in Australia and Europe: a model for emerging infectious diseases. Antiviral Res 2012, 93(3):387-415.

28. Abrantes J, van der Loo W, Le Pendu J, Esteves PJ: Rabbit haemorrhagic disease (RHD) and rabbit haemorrhagic disease virus (RHDV): a review. Vet Res 2012, 43(1):12.

29. Liu L, Botos I, Wang Y, Leonard JN, Shiloach J, Segal DM, Davies DR: Structural basis of toll-like receptor 3 signaling with double-stranded RNA. Science 2008, 320(5874):379-381.

30. Bell JK, Askins J, Hall PR, Davies DR, Segal DM: The dsRNA binding site of human toll-like receptor 3. Proc Natl Acad Sci USA 2006 103(23):8792-8797.

31. Choe J, Kelker MS, Wilson IA: Crystal structure of human toll-like receptor 3 (TLR3) ectodomain. Science 2005, 309(5734):581-585.

32. Areal H, Abrantes J, Esteves PJ: Signatures of positive selection in toll-like receptor (TLR) genes in mammals. BMC Evol Biol 2011, 11(1):368.

33. Offord V, Coffey TJ, Werling D: LRRfinder: a web application for the identification of leucine-rich repeats and an integrative toll-like receptor database. Dev Comp Immunol 2010, 34(10):1035-1041.

34. Chomczynski P, Sacchi N: The single-step method of RNA isolation by acid guanidinium thiocyanate-phenol-chloroform extraction: twenty-something years on. Nat Protoc 2006, 1(2):581-585.
35. Thompson JD, Higgins DG, Gibson TJ, Clustal W: Improving the sensitivity of progressive multiple sequence alignment through sequence weighting, position-specific gap penalties and weight matrix choice. Nucleic Acids Res 1994, 22(22):4673-4680.

36. Hall TA: BioEdit: a user-friendly biological sequence alignment editor and analysis program for windows 95/98/NT. Nucl Acids Symp 1999, 41:95-98.

37. Stephens M, Donnelly P: A comparison of bayesian methods for haplotype reconstruction from population genotype data. Am J Hum Genet 2003, 73(5):1162-1169.

38. Librado P, Rozas J: DnaSP v5: a software for comprehensive analysis of DNA polymorphism data. Bioinformatics (Oxford, England) 2009, 25(11):1451-1452.

doi:10.1186/1471-2156-14-73

Cite this article as: Abrantes et al:: Insights into the European rabbit (Oryctolagus cuniculus) innate immune system: genetic diversity of the toll-like receptor 3 (TLR3) in wild populations and domestic breeds. BMC Genetics 2013 14:73.

\section{Submit your next manuscript to BioMed Central and take full advantage of:}

- Convenient online submission

- Thorough peer review

- No space constraints or color figure charges

- Immediate publication on acceptance

- Inclusion in PubMed, CAS, Scopus and Google Scholar

- Research which is freely available for redistribution 